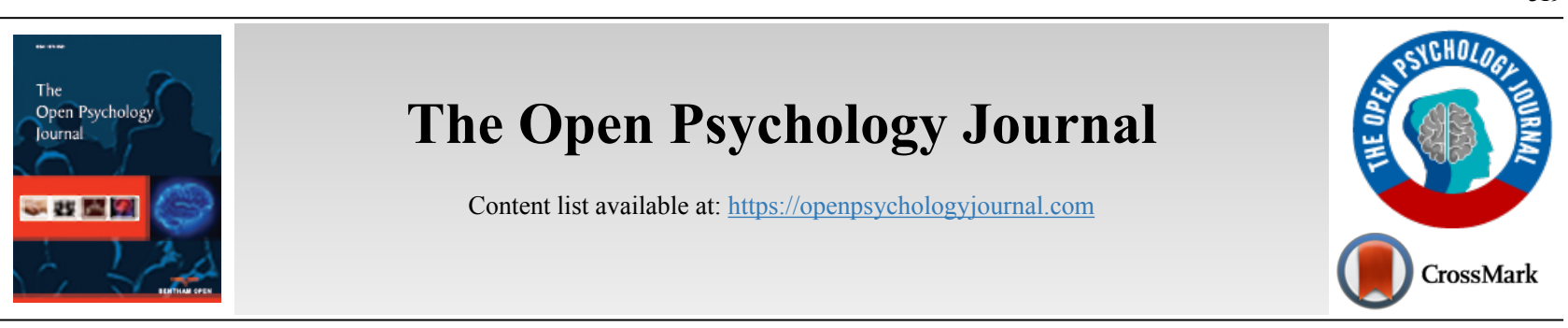

RESEARCH ARTICLE

\title{
Dimensions of Work Environment that Impact Job Satisfaction in Clinical Practices of Medical Students During the SARS-CoV-2 Pandemic
}

\author{
Ricardo Prada ${ }^{1}$, Rodrigo Zarate-Torres ${ }^{2, *}$ and Maria Prada ${ }^{3}$ \\ ${ }^{I}$ Department of School of Administration, Finances, and Economics, Universidad Ean, Colombia \\ ${ }^{2}$ Department of Research, Colegio de Estudios Superiores de Administración, Colombia \\ ${ }^{3}$ Department of Medical School, Universidad del Rosario, Colombia
}

\begin{abstract}
:
Introduction:

This article deals with the relationship between the work environment and job satisfaction in clinical practices of medical students during the SARS-CoV-2 pandemic. Data are presented that attest to the underlying factor structure, reliability, predictive validity, and factors replicability between groups of the summary measure.

Methods:

An initial sample of 132 medical students from 3 different universities in Bogotá who carry out Clinical Practice activities in tertiary hospitals provided data for the exploratory factor analysis of this measure and to apply confirmatory factor analysis techniques. The validated instrument WCA is used for the work environment construct and MSQ for the job satisfaction construct. The potential applications of this measure are described, and the implications of these findings for measuring work environment and satisfaction are discussed.

Results:

The results of the CFA suggest a good global fit to the data of the proposed measurement model, favorable values of significance $(\mathrm{p}=0,014)$; RMR; AGFI; TLI; CFI; GFI, and RMSEA.

Conclusion:

Solid psychometric properties are demonstrated, which prove that there are dimensions of organizational climate that have statistically significant relationships with variables of job satisfaction.
\end{abstract}

Keywords: Labor relations, Work environment, Job satisfaction, Medicine, Minnesota satisfaction questionnaire, SARS-CoV-2 Pandemic.

\begin{tabular}{|l|l|l|l}
\hline Article History & Received: March 25, 2021 & Revised: July 26, 2021 & Accepted: August 12, 2021
\end{tabular}

\section{INTRODUCTION}

Among the various challenges that companies currently face, one of them is the work environment. This environment is permanently affected by the complexity, globalization, and untimely changes in business and society, which equally affect all organizations. Despite this, in some companies, there is still a lack of understanding and a lack of greater commitment to the importance of the work environment and its impact or effects on the employees' job satisfaction; therefore, the achievement of the objectives is increasingly difficult.

\footnotetext{
* Address correspondence to this author at the Department of Research, Colegio de Estudios Superiores de Administración, Colombia; Tel:+57 310570 7073; E-mail: rodrigo.zarate@cesa.edu.co
}

To comply with organizational standards, the management of companies must seek greater effectiveness and relevance in their response to quickly understand the shortcomings that prevent achieving a more pleasant environment that allows employees to work freely and without major inconveniences [1]. An optimal work environment contains the methods and ways of executing the work and encourages the permanence of workers in the organization [2]. Companies that avoid promoting an adequate work environment are internally weak [3], causing a certain level of dissatisfaction at work that will necessarily lead to irregular employee performance.

According to Burton, Lauridsen and Obel [4], the work environment refers to the aggregate perception of people in the organization, which can include the credibility of managers, the 
degree of trust, the level of recognition, and resistance to change. All of these, in one way or another, affect workers' morale. As each work environment of the company is influenced by the interrelation of external and internal factors, such as the structure, the physical environment, the social environment, and the characteristics of the people who make it up [5], it requires differential particularities, since there is no single way to characterize the work environment [6].

Another fundamental element in the composition of the work environment is satisfaction, which according to Wright and Bonett [7], is related to the expression of the feeling experienced by workers and officials in reference to their work, and which also affects, in one way or another, the well-being at work, job performance and the desire to stay in the company $[8]$.

Job satisfaction is vital in general for all companies [9] and represents well-being and motivates employees to remain in their positions [10]. Satisfied workers in their work denote being optimistic, happy, and highly motivated in the fulfillment of their duties. Maintaining this emotion in employees should be a permanent monitoring task of the management of organizations [11].

By the time the study was done, Colombia was experiencing the second peak of the pandemic. It was among the 10 countries with the most infections per million inhabitants, and the government was waiting for the first shipment of doses of the vaccine. In Bogotá in particular, cemeteries had a waiting list to bury the dead. Also, the city experienced many restrictions such as physical distancing, masks or face coverings (mandatory all the time), cleaning and disinfecting of surfaces and objects, wearing of personal protective equipment, and preventing and controlling crowding.

In the medical sector, more than 100 doctors and nurses died. The sector experienced 3 deaths per week and by the time the study was done, the sector had more than 20.000 infected with the virus.

The Clinical Practice is the period between the $7^{\text {th }}$ and $12^{\text {th }}$ academic semester in which the student and future doctor will spend the most time in the clinics and hospitals assigned for their rotation by the different medical services (gynecology, cardiology, general surgery, internal medicine, neurology, traumatology, emergency, among others). These students are faced with continuous shifts lasting 24 to 48 hours. It is understood that they spend most of their week in the hospital, being the 11th and 12th semester students known as interns. They are the ones who practically coexist inside the hospitals.

The sessions are exhausting not only because of their duration but also because of the academic pressure coupled with the suffering observed in the patients. This leads to states of anxiety, tiredness, irritability, drowsiness, and fatigue, which can end with poor performance and sometimes lead to lack of motivation followed by dropouts and significant loss of desire to continue. However, in the current scenario, health organizations are struggling to satisfy future doctors and increase their quality of work life.

The objective of this study is to analyze the impact of the work environment on the job satisfaction of medical students in clinical practices. To this end, it investigates the working conditions in the clinics where the work of the medical students in the last semesters is carried out, considering the variables of the work environment in relation to some specific factors of satisfaction.

\section{LITERATURE REVIEW}

\subsection{The Concept of Working Conditions}

The work environment is related to the motivation to perform well in their work, job security, harmony, and good relationships with co-workers. To reach a high level in the sense of belonging and commitment, management must strive to make employees feel like a fundamental part of the gear and, therefore, important decision-makers within the organization.

According to Spector [12], most managers ignore the work environment within their company, which contributes to the disenchantment and poor performance of their employees. The work has to do not only with the characteristics of each task but also with the forms and ways of doing it, for which it is required to have standards and controls of the activities of the work and their expected results.

However, not all the conditions in which the work is carried out are similar, comfortable, or simple. In fact, in times of pandemic, such as the current one, there are jobs with difficult and risky characteristics for officials, in what has to do with the danger to life and health when carrying them out. Such is the case of medical students in the last semesters, who, like the rest of the personnel responsible for the care and health of patients, face difficult conditions of radiation, temperature, humidity, fatigue, duration of rotation shifts, schedules of work, time off work, the rhythm of work, excessive tension, high responsibility, among others that affect the correct performance of the work.

\subsection{Work Environment}

Appraisals of the work environment, generally referred to as "organizational environment or climate", are substantial organizational behaviors [13]. A contribution of additional effort offered by the employee when exceeding the work goals established by the managers confirms the motivation of the workers and is the result of an effective and pragmatic work environment by the organizations [14]. An effective and pleasant work environment greatly favors the generation of confidence and self-determination of medical students in their clinical practices, ensuring that they will successfully lead them to be better doctors in the immediate future; all of this will result in high-quality patient care [15].

\subsection{Existing Work Environment Measures}

A disagreement has proliferated over the years when deciding the number of dimensions identified as objectives for evaluating the work environment. Such is the case with surveys like the PAHO Organizational Climate Instrument [14], which has 80 items and is too extensive, and the Gallup Q12 [16], which instead of measuring group perceptions of the environment, measures individual employee satisfaction. 
Therefore, they are not adjusted to the needs of small workgroups [17].

Other investigations and proposals for measuring such as the Organizational Climate Questionnaire (OCQ) by Litwin and Stringer [18], which is one of the most used, consists of 50 items that evaluate nine dimensions of the environment. A study by Rogers, Miles and Biggs [19] concludes that the OCQ was not a consistent measurement instrument because it lacked validity. Koys and DeCotiis [20] identified eight key dimensions (autonomy, cohesion, trust, pressure, support, recognition, fairness, and innovation). However, Sims and LaFollette [21], as well as Muchinsky [22], suggest that a sixpiece structure factor is more appropriate and that the nine existing scales showed weak reliability. James and James [23], James and McIntyre [24], and James and Sells [25], propose four dimensions in several different work contexts: (1) role stress and disharmony; (2) job challenge and autonomy; (3) leadership facilitation and support; and (4) cooperation, kindness, and warmth of the working group.

The scale developed by López-Fernández et al. [26] is one of the instruments used in the field of health. Even though it was designed to assess primary health care teams, later, according to Delgado et al. [27], it was used in other health care settings. It consists of 40 items and evaluates four dimensions, cooperation, cohesion, teamwork, social life, and autonomy.

\subsection{Job Satisfaction}

The standard mental state of a person towards his work is the accomplishment of the work [28]. It is the measure of satisfaction that is associated with a job. In that sense, job satisfaction is strongly related to job performance. Satisfaction is one of the most important elements of the work environment, playing an important role in the performance and achievement of results of the organization [29 - 32]. Some of the definitions of job satisfaction are provided in Table $\mathbf{1}$.

The level of the complacency of an employee about his work is rigorously defined and linked to the well-being of the members of the company [33 - 38]. A highly satisfied workforce is an absolute necessity to achieve a high level of advancement in the performance of an organization [33 - 40].

A higher level of job satisfaction in an organization will increase the permanence of the company, reducing the percentage of employee turnover, and contribute to making the company more efficient and profitable [35.

\subsection{Existing Measures of Job Satisfaction}

There are several factors that have been studied as measurement variables of job satisfaction, such as the degree of accomplishment at work, the quality of relationships with superiors and colleagues, and prospects for promotion, among others $[41,42]$.

The internal aspect of job satisfaction has been studied separately in previous research, as well as the external aspect or context of job satisfaction, that is, that which is related to the social and physical conditions of work [43 - 45]. As an example, Huang et al. [46] consider that general satisfaction is related to the work environment and the relationship with colleagues.

\section{Table 1. Some definitions of job satisfaction.}

\begin{tabular}{|c|c|}
\hline Dessler [30] & $\begin{array}{c}\text { Degree of Satisfaction of Needs Derived or } \\
\text { Experienced at Work }\end{array}$ \\
\hline $\begin{array}{l}\text { Spetor and Jex } \\
{[31]}\end{array}$ & $\begin{array}{l}\text { Degree of satisfaction of a person with the job, } \\
\text { which is correlated with the salary, the way of } \\
\text { increasing the salary, the working hours, the work } \\
\text { environment, the possibilities of being promoted, } \\
\text { the interpersonal relationships, and the } \\
\text { management style. }\end{array}$ \\
\hline Rudolph et al. [32] & $\begin{array}{l}\text { Individual attitude towards the current position, } \\
\text { affective response and general feeling of the work } \\
\text { process. }\end{array}$ \\
\hline \begin{tabular}{|c|} 
Krishnan and Nor \\
{$[33]$}
\end{tabular} & General individual attitudes towards work. \\
\hline Crum et al. [34] & $\begin{array}{l}\text { Linked to stress mindset theory. Personal } \\
\text { subjective judgment of work, work process, work } \\
\text { outcome, work experience, and work role, as a } \\
\text { reaction of affect, emotion, or evaluation. }\end{array}$ \\
\hline \begin{tabular}{|c|} 
Boamah, Read and \\
Laschinger [35]
\end{tabular} & $\begin{array}{l}\text { A kind of compromised factor that is related to } \\
\text { business effectiveness }\end{array}$ \\
\hline Zacher et al. [36] & $\begin{array}{l}\text { Degree of like or dislike of an employee for the } \\
\text { job }\end{array}$ \\
\hline $\begin{array}{l}\text { Niemiec and } \\
\text { Spence [37] }\end{array}$ & $\begin{array}{l}\text { Degree to which employees are measured to } \\
\text { resemble their work and they certainly are not. }\end{array}$ \\
\hline $\begin{array}{c}\text { Brown, Wey and } \\
\text { Foland [38] }\end{array}$ & $\begin{array}{c}\text { Perception based on desire, needs, motivation and } \\
\text { the work environment. }\end{array}$ \\
\hline
\end{tabular}

Huang et al. [46] propose 2 dimensions for job satisfaction, one external and one internal. In internal satisfaction, they study the variables of ability, achievement, authority, independence, morality, responsibility, guarantee, creativeness, social service, social status, and diversity; while in the other variable, external satisfaction, they propose to work on promotion, company policy, salary, identity, relationship with the supervisor, and technology.

For this study, satisfaction will be evaluated using the MSQ questionnaire method (University of Minnesota Satisfaction Questionnaire), taking advantage of the working document by Weiss et al. [47], who propose a short form of the MSQ with 20 questions.

\subsection{Relationships between the Work Environment and Job Satisfaction}

According to Lane et al. [48], different factors within the work environment can affect job satisfaction, like wages, working hours, autonomy granted to employees, and organizational structure, among others.

Some previous works found a link between the conditions of the work environment and the degree of job satisfaction [49 - 55]. In this sense, Hashim, Ahmad and Jamaludin [56] propose that the work environment can be a trigger for the work pressure of workers.

There is a relationship between the work environment and some variables related to behavior and attitude [57]. After the study made by Fleishman [57], some authors have done similar studies and have found that this construct can be linked to 
different factors such as psychological well-being [58], satisfaction [59], commitment [60], and psychosocial risks [61, 62]. In this sense, the impact on behavior, physiology, and health is highlighted, among other afflictions that necessarily lead to absenteeism, increased turnover, low work morale, and poor interpersonal relationships [63 - 65]. Therefore, the following hypothesis is suggested:

\subsection{1. $\mathrm{HI}$}

The work environment in hospitals is directly related to the level of job satisfaction of Medicine students in clinical practices during the SARS-CoV-2 Pandemic.

\section{METHODS}

Methodologically, the research consists of descriptive work with a quantitative approach to obtain information or data through studies carried out with the respondents. Through the use of quantitative data, this work seeks to find and acquire exact data on the work environment in clinics and hospitals and its relationship with the job satisfaction of medical students in the last semesters (Fig. 1).

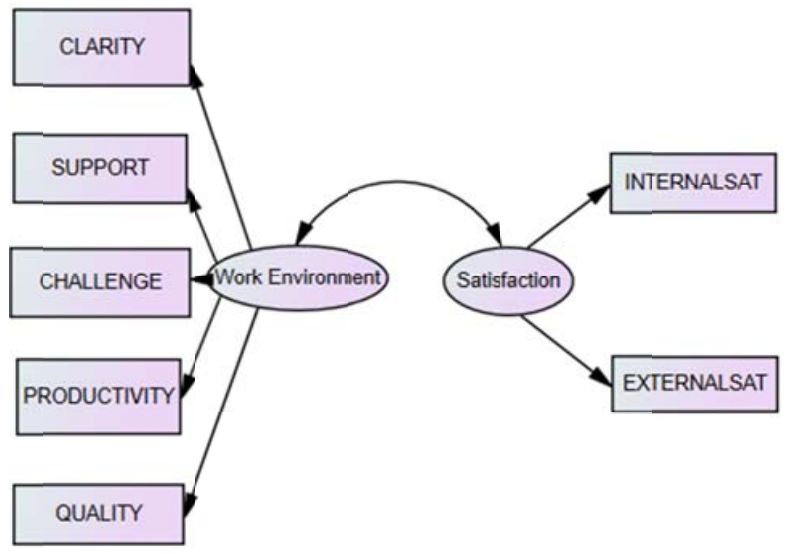

Source: Own elaboration

Fig. (1). A conceptual model of working environment and job satisfaction.

\subsection{Population and Sample Size}

This research selected students of medicine from advanced semesters $\left(7^{\text {th }}\right.$ to $\left.12^{\text {th }}\right)$ and who are currently engaged in rotating services, in clinical practices for assigned hospitals and clinics. Students from 3 high-quality universities and/or medical schools in Bogotá were selected. The questionnaires were distributed to medical students from various universities using the stratified random sampling method. The participants were $51 \%$ women and $49 \%$ men with a mean age of 24 years.

\subsection{Measurements and Tools}

The variables work environment and job satisfaction are used in this study. For the evaluation of the work environment, the Work Group Environment Assessment Tool (WCA) was used, that is, a self-assessment form that contains 14 items: the first 12 items correspond to three sub-dimensions of the work environment - clarity, support, and challenge - and the other 2 items that measure perceptions of productivity and quality. These subdimensions and individual elements are based on the work of George Litwin and Robert Stringer [66]. The WCA is designed to measure the work environment among working groups in the health sector of developing countries.

For the satisfaction evaluation, the MSQ questionnaire method (Satisfaction Questionnaire of the University of Minnesota) was used in its short form of 20 questions. Job satisfaction, in this case, is distributed in 2 dimensions (internal satisfaction and external satisfaction). These two categories are distributed in the instrument as follows:

- Internal satisfaction (questions: 1, 2, 3, 4, 7, 8, 9, 10, $11,15,16$, and 20)

- External satisfaction (questions: 5, 6, 12, 13, 14, 17, 18 , and 19)

This study adopted the Likert scale, which was divided into 5 levels, that is, "Totally disagree", "Disagree", "Neither agree nor disagree", "Agree" and "Totally agree". These levels were assigned from 1 to 5 points, respectively.

\subsection{Collection and Processing of the Data}

One hundred fifty anonymous questionnaires were distributed, and 137 responses were collected, discarding 5 of them because they were incomplete. Data collection took place between August and November 2020. The sample includes students from the $7^{\text {th }}$ semester and up to the $12^{\text {th }}$ semester who worked in the health units of clinics and hospitals in Bogotá. The students were informed of the purpose of the questionnaire and that their participation was voluntary. The students were also acknowledged that their responses are confidential and that they are going to be used only for research purposes.

\subsubsection{Reliability}

In order to verify the consistency of the Satisfaction construct questions, the internal reliability analysis of the presurvey data was performed by calculating the Cronbach Alpha coefficient [67] through SPSS 24 statistical software. The results of the pre-survey show that Cronbach's coefficients of the work environment scale and job satisfaction were 0.816 and 0.926 , respectively, both results greater than 0.8 , which results in high-reliability values.

For the final application of the questionnaires, the reliability analysis is carried out in total for all categories and not for each. Data processing and results show that Cronbach's Alpha coefficient is 0.931 , which means that the instrument is viable because the result is greater than 0.8 . The reliability of the queries used is confirmed. Consequently, the results of the statistical analysis below are considered safe.

\section{RESULTS}

Table 2 presents the distribution of the respondents by gender, age, and level of study. Of the 132 respondents who were included in this study, $49 \%$ are men, and $51 \%$ are women. Most of the respondents are between 23 and 24 years old, that is, $65,9 \%$ of all, and $28 \%$ of them, are 25 years old. Regarding the level of study, in Table 1, it can be seen that the largest 
number of respondents is in the last semester of medicine, that is, $53.8 \%$ of all. $44.7 \%$ are made up of students in semesters 10 and 11 . With these data, it is guaranteed that the survey reflects the feelings of the most mature and experienced group in clinical practice activities.

Table 3 shows the descriptive indicators of the variables provided. It is observed from the responses that the Productivity item $(M=3.99)$ and the Quality item $(M=3.61)$ are the highest rated values, which would indicate that the students are satisfied with the productivity and quality results offered in their daily activities in hospitals. However, the students score lower Challenge variables $(\mathrm{M}=3.33)$ and the
Clarity of instructions received in the clinical practice tasks, which denotes that they have to face activities with a lot of pressure and perhaps with not very clear instructions.

Table 4 shows the correlations between the observed variables. It can be extracted from there as a predominant result of the verification of hypothesis 1 . Internal satisfaction is closely related to external satisfaction at a value of 0.84 , which is very good. Likewise, it is related equally with the variables "Clarity" (0.764), with the variable "Support" at a value of 0.795 and, with the variables "Productivity" and "Quality" at values of 0.578 and 0.69 , respectively. There is no positive correlation with the variable "Challenge".

Table 2. Distribution of respondents by age, gender, and level of study.

\begin{tabular}{|c|c|c|c|c|c|c|}
\hline \multicolumn{2}{|c|}{} & Frequency & Percent & Valid Percent & Cumulative Percent \\
\hline \multirow{4}{*}{ Age } & $21-22$ years & 8 & 6.1 & 6.1 & 6.1 \\
\cline { 2 - 7 } & $23-24$ years & 87 & 65.9 & 65.9 & 72.0 \\
\cline { 2 - 7 } & 25 years & 37 & 28.0 & 28.0 & 100.0 \\
\cline { 2 - 7 } & Total & 132 & 100.0 & 100.0 & \\
\hline \multirow{3}{*}{ Gender } & Male & 65 & 49.2 & 49.2 & 49.2 \\
\cline { 2 - 7 } & Female & 67 & 50.8 & 50.8 & 100.0 \\
\cline { 2 - 7 } & Total & 132 & 100.0 & 100.0 & \\
\hline \multirow{4}{*}{ Level of study } & $7^{\text {th }}$ semester & 1 & 0.8 & 0.8 & 0.8 \\
\cline { 2 - 7 } & $8^{\text {th }}-9^{\text {th }}$ semester & 1 & 0.8 & 0.8 & 1.5 \\
\cline { 2 - 7 } & $10^{\text {th }}-11^{\text {th }}$ semester & 59 & 44.7 & 44.7 & 46.2 \\
\cline { 2 - 7 } & $12^{\text {th }}$ semester & 71 & 53.8 & 53.8 & 100.0 \\
\cline { 2 - 7 } & Total & 132 & 100.0 & 100.0 & \\
\hline
\end{tabular}

Table 3. Descriptive statistics.

\begin{tabular}{|c|c|c|c|c|c|c|c|c|}
\hline \multicolumn{2}{|c|}{-} & Clarity & Support & Challenge & Productivity & Quality & Internalsat & Externalsat \\
\hline \multirow{2}{*}{$\mathrm{N}$} & Valid & 132 & 132 & 132 & 132 & 132 & 132 & 132 \\
\cline { 2 - 9 } & Missing & 0 & 0 & 0 & 0 & 0 & 0 & 0 \\
\hline \multicolumn{2}{|c|}{ Mean } & 3.33 & 3.56 & 3.33 & 3.99 & 3.35 & 3.61 & 3.63 \\
\hline \multicolumn{2}{|c|}{ Std. Deviation } & 0.838 & 0.908 & 0.936 & 1.008 & 1.302 & 0.707 & 0.794 \\
\hline \multicolumn{2}{|c|}{ Skewness } & 0.440 & -0.392 & -0.069 & -1.076 & -.273 & -0.327 & -0.357 \\
\hline \multicolumn{2}{|c|}{ Kurtosis } & -0.402 & -0.431 & -0.521 & 0.905 & -1.126 & -0.123 & 0.007 \\
\hline
\end{tabular}

Table 4. Correlations.

\begin{tabular}{|c|c|c|c|}
\hline \multirow{2}{*}{ Internalsat } & - & Internalsat & Externalsat \\
\cline { 2 - 4 } & Pearson Correlation & 1 & $0.840^{* *}$ \\
\hline \multirow{2}{*}{ Externalsat } & Sig. (2-tailed) & & 0.000 \\
\cline { 2 - 4 } & Pearson Correlation & $0.840^{* *}$ & 1 \\
\hline \multirow{2}{*}{ Clarity } & Sig. (2-tailed) & 0.000 & $0.645^{* *}$ \\
\cline { 2 - 4 } & Pearson Correlation & $0.764^{* *}$ & 0.000 \\
\hline \multirow{2}{*}{ Support } & Sig. (2-tailed) & 0.000 & $0.723^{* *}$ \\
\cline { 2 - 4 } & Pearson Correlation & $0.795^{* *}$ & 0.000 \\
\hline \multirow{2}{*}{ Challenge } & Sig. (2-tailed) & 0.000 & -0.015 \\
\cline { 2 - 4 } & Pearson Correlation & -0.046 & 0.868 \\
\hline Productivity & Sig. (2-tailed) & 0.600 & $0.741^{* *}$ \\
\cline { 2 - 4 } & Pearson Correlation & $0.578^{* *}$ & 0.000 \\
\hline
\end{tabular}


(Table $\square$ ) contd......

\begin{tabular}{|c|c|c|c|}
\hline & & Internalsat & Externalsat \\
\hline \multirow[t]{2}{*}{ Quality } & Pearson Correlation & $0.690^{* *}$ & $0.804^{* *}$ \\
\hline & Sig. (2-tailed) & 0.000 & 0.000 \\
\hline
\end{tabular}

On the other hand, external satisfaction is well related to the variables "Clarity" $(0,645)$, "Support" $(0,723)$, "Productivity" $(0,741)$ and "Quality" $(0,804)$. There is no positive correlation with the variable "Challenge".

Table 5. KMO and sphericity Bartlett's test for the work environment construct.

\begin{tabular}{|l|c|c|}
\hline \multicolumn{2}{|c|}{ Kaiser-Meyer-Olkin Measure of Sampling Adequacy. } & \multicolumn{1}{|c|}{} \\
\hline Bartlett's Test of Sphericity & Approx. Chi-Square & 641.313 \\
\cline { 2 - 3 } & Df & 66 \\
\cline { 2 - 3 } & Sig. & 0.000 \\
\hline
\end{tabular}

Table 6. Total variance explained.

\begin{tabular}{|c|c|c|c|c|c|c|c|c|c|}
\hline \multirow{3}{*}{ Component } & \multicolumn{3}{|c|}{ Initial Eigenvalues } & \multicolumn{2}{c|}{ Extraction Sums of Squared Loadings } & \multicolumn{2}{c|}{ Rotation Sums of Squared Loadings } \\
\cline { 2 - 9 } & Total & \% of Variance & Cumulative \% & Total & \% of Variance & Cumulative \% & Total & \% of Variance & Cumulative \% \\
\hline 1 & 4.260 & 60.855 & 60.855 & 4.260 & 60.855 & 60.855 & 4.258 & 60.823 \\
\hline 2 & 1.021 & 14.590 & 75.445 & 1.021 & 14.590 & 75.445 & 1.024 & 14.622 & 75.445 \\
\hline
\end{tabular}

Extraction Method: Principal Component Analysis.

When rotating, a new component matrix is obtained, which can be seen in Table 7.

The KMO result obtained for the Work Environment construct is 0.834 , which means that, according to Hutchenson and Sofroniou [68], it is quite significant, as it is higher than the 0.7 level. Bartlett's sphericity test with a prominence value of 0 also indicates that it is possible to continue with factor analysis $(\mathrm{p}<0.05)$. The summary can be seen in Table $\mathbf{5}$.

The KMO result obtained for the Work Environment construct is 0.834 , which means that, according to Hutchenson and Sofroniou [68], it is quite significant, as it is higher than the 0.7 level.

Table 6 shows the total explained variance of each component and which are the components that have been extracted (those whose eigenvalues exceed unity). The first two factors all have variances (eigenvalues) greater than 1, and between the two, they collect $75.5 \%$ of the variance of the original variables.

Table 7. Rotated component matrix ${ }^{a}$

\begin{tabular}{|c|c|c|}
\hline \multirow{2}{*}{} & \multicolumn{2}{|c|}{ Component } \\
\cline { 2 - 3 } & $\mathbf{1}$ & $\mathbf{2}$ \\
\hline Externalsat & 0.947 & \\
\hline Internalsat & 0.930 & \\
\hline Support & 0.833 & \\
\hline Quality & 0.823 & \\
\hline Clarity & 0.781 & \\
\hline Productivity & 0.717 & \\
\hline Challenge & & 0.967 \\
\hline
\end{tabular}

Extraction Method: Principal Component Analysis.

Rotation Method: Varimax with Kaiser Normalization.

a. Rotation converged in 3 iterations.

Once the requirements for the EFA with Varimax rotation are tested, this model is verified using Pearson's Confirmatory Factor Analysis (CFA). A confirmatory factor analysis was performed using the maximum likelihood (ML) estimation method.

Using the IBM AMOS software, the measurement and relationship model between the two constructs was built with the sample data. The final solution (standardized estimates) for the analyzed model is represented graphically in Fig. (2). The model obtained relates each of the observed variables or items with the unobserved variables or constructs of Work Environment (14 items) and Job Satisfaction (20 items).

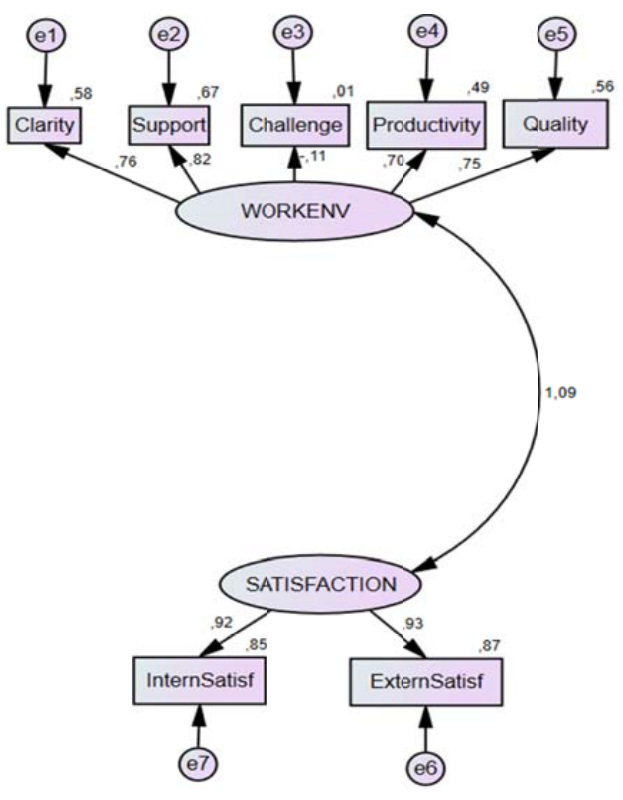

Fig. (2). AFC model of two correlated factors (standardized solution).

The results of the CFA are seen in Tables $\mathbf{8}$ and $\mathbf{9}$. They suggest a good global fit to the data of the proposed 
measurement model with a result of chi-square $=12.432 ; \mathrm{gl}=$ $4 ; p=0.014$.

Table 8. Characteristics of the goodness of fit-scale in study.

\begin{tabular}{|c|c|}
\hline Characteristic & Estimating \\
\hline Proportion to the degree of freedom chi-square (X2/df) & 3.1 \\
\hline $\begin{array}{c}\text { Square root of the variance estimation error of } \\
\text { approximation (RMSEA) }\end{array}$ & 0.04 \\
\hline Fit index (GFI) & 0.97 \\
\hline Adjusted index goodness of fit (AGFI) & 0.904 \\
\hline
\end{tabular}

Table 9. Significance level for covariance.

\begin{tabular}{|c|c|c|c|c|c|c|c|}
\hline- & - & - & Estimate & S.E. & C.R. & P & Label \\
\hline Work envir & $<-->$ & Satisfaction & 0,413 & 0,058 & 7,168 & $* * *$ & - \\
\hline
\end{tabular}

Because the significance value $(p=0,014)$ is greater than 0,01 , it is proven that the model has a good fit. Furthermore, adequate values are obtained at $\mathrm{RMR}=0.024$; $\mathrm{AGFI}=0.904$; $\mathrm{TLI}=0.958 ; \mathrm{CFI}=0.983 ; \mathrm{GFI}=0.97 ; \mathrm{RMSEA}=0.04$.

It is then verified that the items adequately represent the unobserved variables, that is, with these results that the factor loadings that represent the correlations between items and constructs are significant.

\subsection{Test of the Measurement Model}

The goodness of fit scale for this study is shown in Table 8. This graph shows the data from this study and the factorial structure of this scale, the goodness fit, and this shows the alignment of these questions with the structures of a scale.

Table 9 means that the probability of obtaining a critical ratio as large as 7,168 in absolute value is less than 0,001 . In other words, the covariance between Work Environment and Satisfaction is significantly different from zero at the 0.001 level (two-tailed). These statements are approximately correct for large samples under proper assumptions.

\section{DISCUSSION}

This study has examined the working environment and degree of job satisfaction by taking as research subjects the medical students of last semesters who were developing their clinical practices in third-level hospitals in Bogota. The fact that there is a correlation between two variables does not mean that one causes the other, but that does not mean that if we find a correlation between two variables, we can automatically rule out that one is the cause of the other. In this case, as our data have been obtained through a solid experimental design, a positive correlation between variables would be significant evidence of causality.

Given the complexity of these pandemic times, which greatly affects health personnel, among others, 132 valid questionnaires were collected using the tiered random sampling method. The factorial analysis method and the structural equation model were used to conduct an empirical study of the level of association between the working environment and the job satisfaction of medical students in the last semesters.
The article involves two variables, namely the working environment and job satisfaction. The results of the pre-survey show that Cronbach's coefficients of the work environment scale and job satisfaction were 0.816 and 0.926 , respectively, greater than 0.8 and fall within the scope of high reliability. The results of exploratory factor analysis show that the work environment and job satisfaction have a good structure validity, which may reflect the actual situation of and the job satisfaction of medical students in the last semesters.

The values and data obtained in the results make it possible to conclude that in this particular case, there is a sufficient and positive relationship between the variable working environment and job satisfaction, as the subject of study. Together, the correlations between the two types of variables confirm the validity of the subscales of both variables, corroborating the hypothesis proposed at the beginning.

The scales used for the measurement of the Work Environment (WCA) and Job Satisfaction (MQS) were validated by this sample. Therefore they can be used to contribute to the improvement of the quality of service given by medical students to their first patients. It can also help improve the management of health service providers in a better way.

\subsection{On the Working Environment}

The work environment proposed in this research work was worked with the instrument developed and called Workgroup Climate Assessment (WCA), which was developed by the Management Sciences for Health Department of the USA. The WCA is a simple, reliable, and validated tool designed to measure the climate in working groups; it is very useful for health organizations. It consists of 14 items for 5 dimensions: Clarity, Support, Challenge, Productivity, and Quality. The first 12 questions are distributed in an orderly fashion between the Dimensions Clarity, Support and Challenge, in that order. Items 13 and 14 correspond to Productivity and Quality, respectively.

For the "Working Environment" variable, the results, in general, are acceptable. Among the items with the best valuation are 2 of the items related to "Support at work". In particular, item 6 , which corresponds to the statement "We strive to improve our performance" shows that despite the difficult circumstances of pandemic work, medical students in work practice denote the effort they put into their activities, as expected. However, items 12 "We adapt quickly to the new circumstances" and 9 "We seek to understand the needs of our customers", are the points with the lowest rating. These results explain the difficulty of working with the various protocols of assistance and biosecurity, which, coupled with controls and exposures to risk, makes the work of medical students in clinical practice more complicated. It is also important to mention the degree of additional effort for these students when facing a novel situation from the adverse for them, as is to be able to understand and attend the different situations of the patients who enter hospitals with COVID-19 impacts.

\subsection{On Job Satisfaction}

The job satisfaction proposed in this study is based on the 
Minnesota Question of Satisfaction. The short questionnaire consisting of 20 items is worked on. It is based on generating 20 questions built on the central question "How satisfied am I with this aspect of my work?" to medical students. The reported levels of overall job satisfaction in the results of these future physicians were reasonably good. In particular, one of the individual attributes with the highest score on the Job Satisfaction Scale was item 4 "The opportunity to be "someone" in the community", and that corresponds to the subclassification of Internal Satisfaction items, which is framed as something positive and flattering, by the fact that medical students despite the pandemic, somehow enjoy their work and feel that they are contributing to the community.

As for external satisfaction, item 13 was the best rated and corresponded to "The amount of work I do". It is extracted from the above, which for medical students is not relevant. On the response obtained in item 13 , observation is key since it does not coincide with some previous studies that evaluate this characteristic poorly due to the fact that officials are displeased with having been transferred to positions or occupations that they do not enjoy. The causes of this type of difference may be that medical students of last semesters and who begin their clinical practice focus more on their personal development but less on salary and well-being.

The current study, however, suggests that it should be improved in terms of the sense of achievement at work as well as the possible absence of stimuli or manifestations of gratitude received for doing a good job, as can be collected from the responses to items 19 and 20, which were the ones that qualified with lower values among all the points of the questionnaire.

The results of the confirmatory factor analysis show that the seven-factor job satisfaction model has better goodness of fit compared to the single-factor model and six-factor models and can better reflect the composition of job satisfaction of the early years of career faithfully employed.

In the current study, the researchers relied on a questionnaire of 20 items, as already mentioned. In the future, however, further factors could be explored. In addition, this research studied the direct role of job satisfaction of medical students in last semesters who are close to receiving the issues of clinical practices in times of pandemic; however, the researchers did not consider it a variable of intermediation between the working environment and job satisfaction.

Through empirical results, the rationality of job satisfaction is confirmed as a higher-order factor and demonstrates the significant negative effect of the work environment on job satisfaction. Although this article has advanced in a 20dimensional model, it has not considered all the factors that influence it. Research data came from medical students in the last semesters, who are influenced by the great motivation of starting their clinical life, but from the reality of persistent pandemic complexity.

Medical students in the last semesters are in the learning and career development stage, and their job satisfaction in terms of job competence is quite low. However, starting to actually practice in their career predisposes them and motivates them to improve their own ability to work through learning to achieve work competence.

\section{CONCLUSION}

This study analyzed the level of satisfaction of medical students in the last semesters in relation to their work environment, where they deal with complicated and complex situations in hospitals and clinics due to the current health crisis of the pandemic.

In general, it can be concluded from the results obtained that medical students in the last semesters are very satisfied with the work they perform within hospitals, at a level that can be classified from medium to high.

The answers obtained that the Productivity item $(\mathrm{M}=3.99)$ and the Quality item $(M=3.61)$ are the values rated as the highest, which would indicate that the students are satisfied with the productivity results and the quality offered in their daily activities in hospitals. However, the students score lower on the Challenge variables $(M=3.33)$ and the Clarity of instructions received in the clinical practice tasks, which denotes that they have to face activities with a lot of pressure and perhaps with not very clear instructions.

Similarly, it can be concluded that the satisfaction of internal factors (activity, independence, creativity, security, social status, among others) is very similar to the results of external satisfaction (human relations, remuneration, colleagues, working conditions, etc). The foregoing allows us to infer that, in general, students are highly motivated and eager for great learning in their future roles as doctors.

The links find theoretical support since the characteristics of the research allow to verify that there are statistically significant relationships between the job satisfaction constructs and the work environment construct, in all the observed variables: Clarity, Support, Challenge, Productivity, and Quality of work. Close relationships with internal and external satisfaction are observed in the case of medical students in the last semesters who are doing their clinical practices, as a previous stage to become doctors.

The emphasis in this work on the measurement of the constructs, as well as the use of exploratory and confirmatory factor analysis with the variables, allows corroborating the influence of the work environment on job satisfaction in medical students in the last semesters. These results will be decisive for the directorates and managers of human talent in institutions that provide health services in Colombia to better understand the importance of a good work environment with health personnel, especially in those who are just beginning their dedication in such hospitals and clinics. From there, other future studies can be developed and will be a valuable support for the findings.

\section{LIMITATION OF THE STUDY}

The study can be strengthened by increasing the sample size since the results and findings of the data analysis can vary substantially when the sample size increases or decreases. Due to the fact that the population under study corresponds to only three medical schools, it is possible that the results obtained do 
not represent all the medical universities in Bogotá; therefore, greater participation of the universities would generate more precise results and findings. A more detailed empirical study can be carried out with larger sample size between the independent variables and the variables that have multiple categories.

For future research projects, it is suggested to apply other self-report instruments simultaneously to establish convergent validity with the behavior subscale since the self-report measures do not correlate with the appropriate behavior means.

\section{ETHICAL STATEMENT}

Not applicable.

\section{HUMAN AND ANIMAL RIGHTS}

Not applicable.

\section{CONSENT FOR PUBLICATION}

All the students received, within the survey format, complete information on the objective of the research. They were invited to participate voluntarily in answering the questions of the questionnaire by means of instructions at the beginning of the instrument.

\section{AVAILABILITY OF DATA AND MATERIALS}

The data supporting the findings of the article is available from corresponding author [R. Z.-T.] upon reasonable request.

\section{FUNDING}

None.

\section{CONFLICT OF INTEREST}

The authors declare no conflict of interest, financial or otherwise.

\section{ACKNOWLEDGEMENETS}

Declared none.

\section{REFERENCES}

[1] Brown SP, Leigh TW. A new look at psychological climate and its relationship to job involvement, effort, and performance. J Appl Psychol 1996; 81(4): 358-68. [http://dx.doi.org/10.1037/0021-9010.81.4.358] [PMID: 8751453]

[2] Nair A. Meta-Analysis of the relationship between quality management practices and firm performance-implications for quality management theory development. J Oper Manage 2006; 24: 948-75. [http://dx.doi.org/10.1016/j.jom.2005.11.005]

[3] Aiken LH, Clarke SP, Sloane DM. Hospital staffing, organization, and quality of care: Cross-national findings. Nurs Outlook 2002; 50(5): 187-94.

[http://dx.doi.org/10.1067/mno.2002.126696] [PMID: 12386653]

[4] Burton RM, Lauridsen J, Obel B. The impact of organisational climate and strategic fit on firm performance. Hum Resour Manage 2004; 43: $67-82$.

[http://dx.doi.org/10.1002/hrm.20003]

[5] Ehrhart MG, Schneider B, Macey WH. Organizational climate and culture: An introduction to theory, research, and practice. New York: Routledge 2014.

[6] DeJoy DM. Toward a comprehensive human factors model of workplace accident causation. Prof Saf 1990; 35(5): 11-6. [http://dx.doi.org/10.1518/107118188786761910]

[7] Wright TA, Bonett DG. Job satisfaction and psychological well-being as nonadditive predictors of workplace turnover. J Manage 2007; 33(2): 141-60.

[http://dx.doi.org/10.1177/0149206306297582]

[8] Singh P, Loncar N. Pay satisfaction, job satisfaction and turnover intent. Relations industrielles/industrial relations 2010; 65(3): 470-90. [http://dx.doi.org/10.7202/044892ar]

[9] Ostroff C. Comparing correlations based on individual-level and aggregated data. J Appl Psychol 1993; 78: 569-82.

[http://dx.doi.org/10.1037/0021-9010.78.4.569]

[10] Tett RP, Meyer JP. Job satisfaction, organizational commitment, turnover intention, and turnover: path analyses based on meta-analytic findings. Person Psychol 1993; 46: 259-93.

[http://dx.doi.org/10.1111/j.1744-6570.1993.tb00874.x]

[11] Mitchell TR, Holtom BC, Lee TW, Sablynski CJ, Erez M. Why people stay: Using Job embeddedness to predict voluntary turnover. Acad Manage J 2001; 44: 1102-21.

[http://dx.doi.org/10.2307/3069391]

[12] Spector PE. Job satisfaction: application, assessment, cause, and consequences. USA: SAGE Publications, Inc. 1997.

[13] Rousseau DM. The construction of climate in organization research. In: Cooper CL, Robertoson IT, Eds. International Review of Industrial and Organizational Psychology. Chichester: Wiley 1988; Vol. 3: pp. 139-59.

[http://dx.doi.org/10.1177/017084068901000317]

[14] Cullen P. 2019.Half of Ireland's hospital doctors exhausted and overwhelmed by work ttps://www.irishtimes.com /news/health/halfofireland-s-hospital-doctors-exhausted-and-

[15] Thomas S, Burke S, Barry S. The Irish health-care system and austerity: sharing the pain. Lancet 2014; 383(9928): 1545-6. [http://dx.doi.org/10.1016/S0140-6736(14)60744-3] [PMID: 24792851]

[16] Maybury C. The European working time directive: a decade on Lancet 2014; 384(9954): 1562-3.

[http://dx.doi.org/10.1016/S0140-6736(14)61972-3]

[PMID 25473669]

[17] Collins A, Beauregard A. The effect of breaches of the psychological contract on the job satisfaction and wellbeing of doctors in Ireland: a quantitative study. Hum Resour Health 2020; 18(1): 89.

[http://dx.doi.org/10.1186/s12960-020-00534-3] [PMID: 33183316]

[18] Litwin G, Stringer R. Motivation and organizational climate. Boston: Harvard Business School Press 1968.

[19] Rogers ED, Miles WG, Biggs WD. The factor replicability of the litwin and stringer organizational climate questionnaire: An inter- and intra-organizational assessment. J Manage 1980; 6: 65-78. [http://dx.doi.org/10.1177/014920638000600105]

[20] Koys DJ, DeCotiis TA. Inductive measures of psychological climate. Hum Relat 1991; 44: 265-85.

[http://dx.doi.org/10.1177/001872679104400304]

[21] Sims HP, LaFollette W. An assessment of the Litwin and Stringer Organizational Climate Questionnaire. Person Psychol 1975; 28: 19-38.

[http://dx.doi.org/10.1111/j.1744-6570.1975.tb00388.x]

[22] Muchinsky PM. An assessment of the litwin and stringer organizational climate questionnaire: An empirical and theoretical extension of the sims and lafollette study. Person Psychol 1976; 29: 371-92.

[http://dx.doi.org/10.1111/j.1744-6570.1976.tb00422.x]

[23] James LA, James LR. Integrating work environment perceptions: explorations into the measurement of meaning. J Appl Psychol 1989; 74: 739-51.

[http://dx.doi.org/10.1037/0021-9010.74.5.739]

[24] James LR, McIntyre MD. Perceptions of organizational climate.Individual differences and behavior in organizations. San Francisco, CA: Jossey-Bass 1996; pp. 416-50.

[25] James LR, Sells SB. Psychological climate: theoretical perspectives and empirical research.Toward a psychology of situations: An interactional perspective. Hillsdale, NJ: Erlbaum 1981; pp. 275-92.

[26] López-Fernández LA, Sánchez-Cantalejo E, Calzas-Urrutia A, SilesRomán D, Sevilla-García E, De Oleaga-Usátegui I. Elaboration of a questionnaire for the study of the organizational climate of the centers of Health. Aten Primary 1988; 5(10): 531-6.

[27] Delgado Sánchez A, Bellón Saameño JA, Martínez-Cañavate LópezMontes MT, Luna del Castillo JdeD, López Fernández LA, Lardelli Claret P. The dimensions of the organizational climate perceived by the family doctors. Aten Primary 2006; 37(9): 489-97.

[http://dx.doi.org/10.1157/13089089] [PMID: 16756872]

[28] Smith P, Kendall L, Hulin C. Measurement of satisfaction in work and 
retirement. Chicago: Rand McNally 1969

[29] Koys DJ. The effects of employee satisfaction, organizational citizenship behavior, and turnover on organizational effectiveness: A unit level, longitudinal study. Person Psychol 2001; 54(1): 101-14. [http://dx.doi.org/10.1111/j.1744-6570.2001.tb00087.x]

[30] Dessler G. Personnel management, modern concept and techniques. Virginia: Reston Publishing Company Inc. 1978.

[31] Spector PE, Jex SM. Development of four self-report measures of job stressors and strain: Interpersonal conflict at work scale, organizational constraints scale, quantitative workload inventory, and physical symptoms inventory. J Occup Health Psychol 1998; 3(4): 356-67. [http://dx.doi.org/10.1037/1076-8998.3.4.356] [PMID: 9805281]

[32] Rudolph CW, Clark MA, Jundt DK, Baltes BB. Differential reactivity and the within-person job stressor-satisfaction relationship. Stress Health 2016; 32(5): 449-62.

[http://dx.doi.org/10.1002/smi.2641] [PMID: 25981457]

[33] Krishnan KST, Nor NM. Employer perception toward safety and health on professionals' commitment, ethics and regulatory compliance in malaysia. Int J Library Sci 2016; 5(2): 21-4. [http://dx.doi.org/10.5923 / j.library.20160502.01]

[34] Crum AJ, Akinola M, Martin A, Fath S. The role of stress mindset in shaping cognitive, emotional, and physiological responses to challenging and threatening stress. Anxiety Stress Coping 2017; 30(4): 379-95

[http://dx.doi.org/10.1080/10615806.2016.1275585]

[PMID 28120622]

[35] Boamah SA, Read EA, Spence Laschinger HK. Factors influencing new graduate nurse burnout development, job satisfaction and patient care quality: a time-lagged study. J Adv Nurs 2017; 73(5): 1182-95. [http://dx.doi.org/10.1111/jan.13215] [PMID: 27878844]

[36] Zacher H, Dirkers BT, Korek S, Hughes B. Age-differential effects of job characteristics on job attraction: A policy-capturing study. Front Psychol 2017; 8(8): 1124 .

[http://dx.doi.org/10.3389/fpsyg.2017.01124] [PMID: 28713322]

[37] Niemiec CP, Spence GB. Optimal motivation at work. In: The Wiley Blackwell Handbook of the Psychology of Positivity and StrengthsBased Approaches at work. 2017; pp. 82-98.

[http://dx.doi.org/10.1002/9781118977620.ch6]

[38] Brown R, Wey H, Foland K. The relationship among change fatigue, resilience, and job satisfaction of hospital staff nurses. J Nurs Scholarsh 2018; 50(3): 306-13

[http://dx.doi.org/10.1111/jnu.12373] [PMID: 29517141]

[39] Ali A, Swiercz P. Managerial decision styles and work satisfaction in saudi arabia. Manage Decis 1985; 23(2): 33-42.

[http://dx.doi.org/10.1108/eb001372]

[40] Pushpakumari M. The impact of job satisfaction on job performance. An Empirical Analysis 2008; 89-105.

[41] Ali A. The Arab executive: a study in values and work orientation. American-Arab Affairs 1986/1987; 19: 94-100.

[42] Pulakos ED, Schmitt N. A longitudinal study of a valence model approach for the prediction of job satisfaction of new employees. J Appl Psychol 1983; 68(2): 307-12.

[http://dx.doi.org/10.1037/0021-9010.68.2.307]

[43] Sousa-Poza A, Sousa-Poza AA. Well-being at work: A cross-national analysis of the levels and determinants of job satisfaction. J SocioEconomics 2000; 29(6): 517-38.

[http://dx.doi.org/10.1016/S1053-5357(00)00085-8]

[44] Gazioglu S, Tanselb A. Job satisfaction in britain: Individual and job related factors. Appl Econ 2006; 38(10): 1163-71.

[http://dx.doi.org/10.1080/00036840500392987]

[45] Skalli A, Theodossiou I, Vasileiou E. Jobs as Lancaster goods: Facets of job satisfaction and overall job satisfaction. J Behav Exp Econ Elsevier 2008; 37(5): 1906-20

[http://dx.doi.org/10.1016/j.socec.2008.04.003]

[46] Huang Y, Xu S, Hua J, et al. Association between job strain and risk of incident stroke: A meta-analysis. Neurology 2015; 85(19): 1648-54. [http://dx.doi.org/10.1212/WNL.0000000000002098] [PMID: 26468409]

[47] Weiss D J, Dawis R V, England G, Lofquist L. Manual for the minnesota satisfaction questionnaire: Minnesota studies in vocational rehabilitation. Minneapolis: Industrial Relations Center, University of Minnesota 1967.
[48] Lane KA, Esser J, Holte B, McCusker MA. A study of nurse faculty job satisfaction in community colleges in florida. Teach Learn Nurs 2010; 5: 16-26.

[http://dx.doi.org/10.1016/j.teln.2009.05.001]

[49] Finnegan MC, Solomon LZ. Work attitudes in windowed vs windowless environments. J Soc Psychol 1981; 115: 291-2.

[http://dx.doi.org/10.1080/00224545.1981.9711674]

[50] Leather P, Pygras M, Beale D, Lawrence C. Windows in the workplace: Sunlight, view and occupational stress. Environ Behav 1998; 30: 739-62

[http://dx.doi.org/10.1177/001391659803000601]

[51] Brill M, Weidemann S \& Bosti. Associates.Disproving widespread myths about workplace design. Kimball International. Jasper. IN 2001.

[52] Newsham G, Veitch J, Arsenault C, Duval C. Effect of dimming control on office worker satisfaction and performance. In: Proceedings of the IESNA annual conference. 2004; pp. 19-41.

[53] Veitch JA, Geerts J, Charles KE, Newsham GR, Marquardt CJG. Satisfaction with lighting in open-plan offices: COPE field findings In: Proceedings of Lux Europa. Berlin, Germany 2005; pp. 414-7.

[54] Kinzl JF, Knotzer H, Traweger C, Lederer W, Heidegger T, Benzer A Influence of working conditions on job satisfaction in anaesthetists. $\mathrm{Br}$ J Anaesth 2005; 94(2): 211-5.

[http://dx.doi.org/10.1093/bja/aei035] [PMID: 15567811]

[55] Newsham G. Linking indoor. Environment conditions to job satisfaction. Build Res Inform 2009; 37(2): 129-47. [http://dx.doi.org/10.1080/09613210802710298]

[56] Hashim RA, Ahmad B, Jamaludin A. Relationship between leadership styles and affective commitment among employees in National AntiDrugs Agency (NADA). Glob Bus Manag Res 2017; 9: 39-51.http://library.oum.edu.my/repository/id/eprint/1194

[57] Fleishman EA. The description of supervisory behavior. J Appl Psychol 1953; 37(1): 1-6.

[http://dx.doi.org/10.1037/h0056314] [PMID: 6038475]

[58] Cummings LL, DeCotiis TA. Organizational correlates of perceived stress in a professional organization. Public Pers Manage 1973; 2: 275-82.

[http://dx.doi.org/10.1177/009102607300200407]

[59] Schnake ME. An empirical assessment of the effects of affective response in the measurement of organizational climate. Person Psychol 1983; 36: 791-807. [http://dx.doi.org/10.1111/j.1744-6570.1983.tb00513.x]

[60] DeCotiis TA, Summers TP. A path analysis of a model of the antecedents and consequences of organizational commitment. Hum Relat 1987; 40: 445-70.

[http://dx.doi.org/10.1177/001872678704000704]

[61] Cullbertson A, Rodgers W. Improving managerial effectiveness in the workplace: The case of sexual harassment of Navy women. J Appl Soc Psychol 1997; 27: 1953-71.

[http://dx.doi.org/10.1111/j.1559-1816.1997.tb01634.x]

[62] Vartia M. The sources of bullying: Psychological work environment and organizational climate. Eur J Work Organ Psychol 2008; 5(2): 203-14.

[http://dx.doi.org/10.1080/13594329608414855]

[63] Cole LL, Grubb PL, Sauter SL, Swanson NG, Lawless P. Psychosocial correlates of harassment, threats and fear of violence in the workplace. Scand J Work Environ Health 1997; 23(6): 450-7. [http://dx.doi.org/10.5271/sjweh.268] [PMID: 9476809]

[64] Liu Y, Aungsuroch Y, Yunibhand J. Job satisfaction in nursing: a concept analysis study. Int Nurs Rev 2016; 63(1): 84-91. [http://dx.doi.org/10.1111/inr.12215] [PMID: 26492403]

[65] Steel RP, Shane GS, Kennedy KA. Effects of social system factors on absenteeism, turnover, and job performance. J Bus Psychol 1990; 4: 423-30. [http://dx.doi.org/10.1007/BF01013605]

[66] Perry C, LeMay N, Rodway G, Tracy A, Galer J. Validating a Work Group Climate Assessment Tool for improving the performance of public health organizations. Hum Resour Health 2005; 3: 10. [http://dx.doi.org/10.1186/1478-4491-3-10] [PMID: 16223447]

[67] Nunnally JC. Psychometric theory. New York: McGraw-Hill 1978.

[68] Hutchenson G, Sofroniou N. The multivariate social scientist: Introductory statistics using generalized linear models. Londres: Ed. Sage Publications 1999.

[http://dx.doi.org/10.4135/9780857028075] 